\title{
Proposal of Virgibacillus proomii sp. nov. and emended description of Virgibacillus pantothenticus (Proom and Knight 1950) Heyndrickx et al. 1998
}

\author{
M. Heyndrickx, ${ }^{1} \dagger$ L. Lebbe, ${ }^{1}$ K. Kersters, ${ }^{1}$ B. Hoste, ${ }^{1}$ R. De Wachter, ${ }^{2}$ \\ P. De Vos, ${ }^{1}$ G. Forsyth ${ }^{3}$ and N. A. Logan ${ }^{3}$
}

Author for correspondence: N. A. Logan. Tel: +44 141331 3207. Fax: +44 1413313208. e-mail: N.A.Logan@gcal.ac.uk

\footnotetext{
1 Vakgroep BFM WE10V, Laboratorium voor Microbiologie, Universiteit Gent, K. L.

Ledeganckstraat 35 , B-9000 Gent, Belgium

2 Department Biochemie, Universiteit Antwerpen, Universiteitsplein 1, B-2610 Antwerpen, Belgium

${ }^{3}$ School of Biological and Biomedical Sciences, Glasgow Caledonian University, Cowcaddens Road, Glasgow G4 OBA, UK
}

\begin{abstract}
A polyphasic study of strains originally received as Bacillus (now Virgibacillus) pantothenticus, along with strains representing species belonging to Bacillus, Halobacillus and Paenibacillus, was undertaken using amplified rDNA restriction analysis (ARDRA), fatty acid methyl ester (FAME) analysis, SDSPAGE of whole-cell proteins and routine diagnostic characters comprising 61 biochemical tests in the API system and 15 observations of vegetative cell and sporangial morphology. It revealed the presence within Virgibacillus of an as yet undescribed new species, for which the name Virgibacillus proomii is proposed; $V$. proomii can be distinguished from $V$. pantothenticus and members of Bacillus sensu stricto, and from members of Paenibacillus and other aerobic endospore-forming bacteria, by routine phenotypic tests. The type strain of Virgibacillus proomii is LMG $12370^{\top}$.
\end{abstract}

Keywords: Bacillus, amplified rDNA restriction analysis, Virgibacillus pantothenticus, Virgibacillus proomii, polyphasic taxonomy

\section{INTRODUCTION}

Bacillus pantothenticus was described by Proom \& Knight (1950) following a nutritional analysis of mesophilic soil isolates of Bacillus species. Strains requiring pantothenic acid were isolated from different soil samples, taken from widely separated localities in Southern England. They considered them as members of a species most closely resembling Bacillus circulans but distinct from it, and subsequent studies confirmed the validity of the species (Claus \& Berkeley, 1986; Gordon et al., 1973; Logan \& Berkeley, 1984). Later isolations have been made from antacids (Claus \& Berkeley, 1986), food, water, bile and soil.

Comparisons of the 16S rRNA sequences of type strains of various Bacillus and Sporosarcina species

\footnotetext{
†Present address: Government Dairy Research Station, Brusselsesteenweg 370, B-9090 Melle, Belgium.

Abbreviations: ARDRA, amplified rDNA restriction analysis; FAME, fatty acid methyl ester; UPGMA, unweighted pair group method with arithmetic averages.

The EMBL accession number for the $16 \mathrm{~S}$ rRNA gene sequence of Virgibacillus
} proomii strain LMG $12370^{\top}$ determined in this work is AJ012667. have indicated that $B$. pantothenticus lies at the periphery of rRNA group 1 of Ash et al. (1991) (Bacillus sensu stricto). Following amplified rDNA restriction analysis (ARDRA) and a polyphasic study, the new genus Virgibacillus (Heyndrickx et al., 1998) was proposed to accommodate $B$. pantothenticus and two related organisms which appeared to belong to an as yet undescribed new species. Polyphasic taxonomic study of further isolates received as $B$. pantothenticus has confirmed the existence within Virgibacillus of a second species which we propose here as Virgibacillus proomii.

\section{METHODS}

Strains and media. The designations of the strains, their origins and the different methods applied are shown in Table 1. Unless otherwise stated, $V$. pantothenticus strains were grown on Trypticase Soy agar (TSA) and the other Bacillus strains on nutrient agar with $1 \%(\mathrm{w} / \mathrm{v})$ glucose (NAG) at $30^{\circ} \mathrm{C}$ for $24-48 \mathrm{~h}$. The Bacillus dipsosauri strain was grown at $37^{\circ} \mathrm{C}$ on TSA supplemented with $1 \mathrm{M} \mathrm{KCl}$. The strains were checked for purity by plating and phase-contrast microscopy, and were maintained both as lyophilized cultures and as sporulated cultures on slopes of the appropriate above-mentioned medium containing $5 \mathrm{mg} \mathrm{MnSO}{ }_{4} \cdot 4 \mathrm{H}_{2} \mathrm{O}$ 
Table 1. Strains used and the methods used for characterization

\begin{tabular}{|c|c|c|c|c|c|c|c|}
\hline \multirow[t]{2}{*}{ Name } & \multirow[t]{2}{*}{ LMG no. } & \multirow[t]{2}{*}{ Other designations* } & \multirow[t]{2}{*}{ Source and comment* } & \multicolumn{4}{|c|}{ Methods applied $\dagger$} \\
\hline & & & & ARDRA & API & PAGE & FAME \\
\hline B. amyloliquefaciens & $9814^{T}$ & B0177 ${ }^{\mathrm{T}}$, Campbell F, ATCC $23350^{\mathrm{T}}$ & Gordon & + & + & & \\
\hline B. amyloliquefaciens & 12234 & B0168, Fukumoto F & Gordon & + & + & & \\
\hline B. azotoformans & $9581^{\mathrm{T}}$ & CCM $2849^{\mathrm{T}}$ & $\mathrm{CCM}$ & + & + & & \\
\hline B. azotoformans & 15444 & Pichinoty $\mathrm{Ba} 3$ & Pichinoty & + & + & & \\
\hline B. badius & $7122^{\mathrm{T}}$ & $\mathrm{B} 0180^{\mathrm{T}}, \mathrm{DSM} 23^{\mathrm{T}}$ & $\mathrm{DSM}$ & + & + & & \\
\hline B. badius & 12332 & B0201, NRS 1407, Appleman & Gordon & + & + & & \\
\hline B. cereus & $6923^{\mathrm{T}}$ & $\begin{array}{l}\text { B0002 } 2^{\mathrm{T}} \text {, DSM } 31^{\mathrm{T}} \text {, ATCC } 14579, \\
\text { Ford } 13\end{array}$ & DSM & + & + & & \\
\hline B. cereus & 12334 & B0358, F 4810/73 (strain 88) & $\begin{array}{l}\text { Vomit, serogroup 1, } \\
\text { Melling }\end{array}$ & + & + & & \\
\hline B. circulans & $13261^{\mathrm{T}}$ & B $0004^{\mathrm{T}}, \mathrm{DSM} 11^{\mathrm{T}}$, ATCC $4513^{\mathrm{T}}$ & DSM & + & + & & \\
\hline B. circulans & $12342 \ddagger$ & B0196, NCTC 5846, Morris & Potted crab, NCTC & + & + & & \\
\hline B. dipsosauri & $17413^{\mathrm{T}}$ & NCFB $3027^{\mathrm{T}}$ & Iguana, NCFB & + & + & & \\
\hline B. firmus & $7125^{\mathrm{T}}$ & B0181 ${ }^{\mathrm{T}}$, DSM $12^{\mathrm{T}}$, ATCC $14575^{\mathrm{T}}$ & DSM & + & + & & \\
\hline B. fusiformis & $9816^{\mathrm{T}}$ & $\begin{array}{l}\text { B0658 }, \text { ATCC } 7055^{\mathrm{T}}, \text { Wellcome } \\
2209\end{array}$ & Goodfellow & + & + & & \\
\hline B. fusiformis & 17347 & B0660, Wellcome 2615 & Goodfellow & + & + & & \\
\hline B. insolitus & $17757^{\mathrm{T}}$ & B0432 $2^{\mathrm{T}}$, Stokes W16 B, DSM $5^{\mathrm{T}}$ & Soil, DSM & + & + & & \\
\hline B. insolitus & 17758 & B0433, Ottow 627 & Goodfellow & + & + & & \\
\hline B. lentus & $9579^{\mathrm{T}}$ & $\begin{array}{l}\text { B } 0779^{\mathrm{T}} \text {, Gibson urea } 165 \text { 'type } \\
\text { culture' }\end{array}$ & Gibson & & + & & \\
\hline B. lentus & 12359 & B0179, Gibson 238, ATCC 10841 & Gibson & + & + & & \\
\hline B. lentus & $16798^{\mathrm{T}}$ & NCIMB $8773^{\mathrm{T}}$ & NCIMB & + & & & \\
\hline B. licheniformis & 12360 & B0242, Gibson 307 & Gibson & + & + & & \\
\hline B. licheniformis & $12363^{\mathrm{T}}$ & B $0245^{\mathrm{T}}, \mathrm{G} 46$, NCTC 10341 & Gibson & + & + & & \\
\hline B. megaterium & $7127^{\mathrm{T}}$ & B $0010^{\mathrm{T}}$, DSM $32^{\mathrm{T}}$, ATCC $14581^{\mathrm{T}}$ & DSM & + & + & & \\
\hline B. megaterium & 12409 & B0621, Hartman NRRL B-348 & Goodfellow & + & + & & \\
\hline B. psychrophilus & $6929^{\mathrm{T}}$ & B0434 ${ }^{\mathrm{T}}$, Stokes W16 A, DSM $3^{\mathrm{T}}$ & DSM & + & + & & \\
\hline B. psychrophilus & 17169 & ATCC 23306 & ATCC & + & + & & \\
\hline B. pumilus & $7132^{\mathrm{T}}$ & B0019, DSM $27^{\mathrm{T}}$, ATCC $7061^{\mathrm{T}}$ & DSM & + & + & & \\
\hline B. pumilus & 12259 & B0102, G 1036, Lister 2812 & Gibson & & + & & \\
\hline B. smithii & 6327 & DSM 459 & DSM & + & + & & \\
\hline B. smithii & $12526^{\mathrm{T}}$ & CCUG 27413 & CCUG & + & + & & \\
\hline B. sphaericus & $7134^{\mathrm{T}}$ & B0012, DSM $28^{\mathrm{T}}$, G 1013 & DSM & + & + & & \\
\hline B. sphaericus & 17382 & B1144, SS II-1 & De Barjac & + & + & & \\
\hline B. subtilis & $7135^{\mathrm{T}}$ & B0014 ${ }^{\mathrm{T}}$, DSM $10^{\mathrm{T}}$, ATCC $6051^{\mathrm{T}}$ & DSM & + & + & + & \\
\hline B. subtilis & 17727 & B0905 & $\begin{array}{l}\text { Cornish pasty, } \\
\text { Sandys }\end{array}$ & + & + & & \\
\hline$V \cdot$ pantothenticus & $7129^{\mathrm{T}}$ & $\begin{array}{l}\text { B0018 }{ }^{\mathrm{T}} \text {, DSM } 26^{\mathrm{T}}, \text { ATCC } 14576^{\mathrm{T}}, \\
\text { NCDO } 1765^{\mathrm{T}}\end{array}$ & Soil, DSM & + & + & + & + \\
\hline$V \cdot$ pantothenticus & 12366 & B0183, DSM 490, NCTC 8122 & DSM & + & + & + & + \\
\hline V.pantothenticus & 12367 & B0184, DSM 491, NCTC 8124 & DSM & + & + & + & + \\
\hline$V \cdot$ pantothenticus & 12368 & $\begin{array}{l}\text { B0275, NCTC } 8123 \text {, Wellcome CN } \\
3020\end{array}$ & Soil, NCTC & + & + & + & + \\
\hline$V \cdot$ pantothenticus & 12369 & B0406, F 2150/77 & $\begin{array}{l}\text { Canned chicken, } \\
\text { Colindale }\end{array}$ & + & + & + & + \\
\hline$V$. pantothenticus & 12370 & B0413, F 2737/77 & $\begin{array}{l}\text { Water supply, } \\
\text { Colindale }\end{array}$ & + & + & + & + \\
\hline$V$. pantothenticus & 12371 & B0417, F 218/78 & Infant bile, Colindale & + & + & + & + \\
\hline$V$. pantothenticus & 17342 & B0802, Wellcome CN 3021 & Soil, Gibson & + & + & + & + \\
\hline$V$. pantothenticus & 17343 & B0803, Wellcome CN 3022 & Soil, Gibson & + & + & + & + \\
\hline$V$. pantothenticus & 17344 & B0805, Wellcome CN 3024 & Soil, Gibson & + & + & + & + \\
\hline$V$. pantothenticus & 17345 & B0806, Wellcome CN 3025 & Soil, Gibson & + & + & + & + \\
\hline
\end{tabular}


Virgibacillus proomii sp. nov.

Table 1 (cont.)

\begin{tabular}{|c|c|c|c|c|c|c|c|}
\hline \multirow[t]{2}{*}{ Name } & \multirow[t]{2}{*}{ LMG no. } & \multirow[t]{2}{*}{ Other designations* } & \multirow[t]{2}{*}{ Source and comment* } & \multicolumn{4}{|c|}{ Methods applied $\dagger$} \\
\hline & & & & ARDRA & API & PAGE & FAME \\
\hline$V$, pantothenticus & 17367 & B0807, Wellcome CN 3026 & Soil, Gibson & + & + & + & + \\
\hline$V$. pantothenticus & 17368 & B0808, Wellcome CN 3027 & Soil, Gibson & + & + & + & + \\
\hline$V$. pantothenticus & 17369 & B0809, Wellcome CN 3043 & Soil, Gibson & + & + & + & + \\
\hline
\end{tabular}

* ATCC, American Collection of Type Cultures, Manassas, VA, USA; B, N. A. Logan Bacillus collection, Glasgow Caledonian University, Glasgow, UK; CCM, Czechoslovakian Collection of Microorganisms, Brno, CSSR; CCUG, Culture Collection University of Göteborg, Göteborg, Sweden; CN, Wellcome Collection of Microorganisms, Beckenham, Kent, UK; Colindale, Central Public Health Laboratory, London, UK; De Barjac, H. De Barjac, Institut Pasteur, Paris, France; DSM, Deutsche Sammlung von Mikroorganismen und Zellkulturen, Braunschweig, Germany; Gibson, T. Gibson collection, held at University of Bristol, Bristol, UK; Goodfellow, M. Goodfellow, University of Newcastle, Newcastle upon Tyne, UK; Gordon, R. E. Gordon, Rutgers University, New Brunswick, USA; LMG, Laboratorium voor Microbiologie, Universiteit Gent, Gent, Belgium; Melling, J. Melling, CAMR, Porton Down, Salisbury, UK; NCFB, National Collection of Food Bacteria, AFRC Institute of Food Research, Reading, UK; NCIMB, National Collection of Industrial and Marine Bacteria, Aberdeen, UK; NCTC, National Collection of Type Cultures, Central Public Health Laboratory, London, UK; NRRL, Northern Regional Research Laboratory collection, Peoria, IL, USA; NRS, N. R. Smith collection, now held at NRRL; Pichinoty, F. Pichinoty, UER Scientifique de Luminy, Marseille, France; Sandys, G. H. Sandys, Public Health Laboratory, Plymouth, UK.

$\uparrow$ API, tests in API system, other biochemical tests and morphological observations; ARDRA, amplified rDNA restriction analysis; FAME, fatty acid methyl ester analysis; PAGE, polyacrylamide gel electrophoresis of whole-cell proteins.

$\ddagger$ Accession number for this strain is now LMG 18014 .

$1^{-1}$ (to enhance sporulation). Slopes were incubated for $48 \mathrm{~h}$ or longer, until spores could be observed by microscopy, then stored in the dark at $4^{\circ} \mathrm{C}$.

DNA preparation. Total genomic DNA was purified for ARDRA using a slight modification of the method of Pitcher et al. (1989), as described previously (Heyndrickx et al., 1996b, 1998). For DNA-DNA binding experiments and DNA base composition studies, DNA was prepared as described previously (Heyndrickx et al., 1996a).

ARDRA. Enzymically amplified 16S rDNA was obtained by PCR and analysed by restriction digestion with five restriction enzymes (HaeIII, DpnII, RsaI, BfaI and Tru9I) as described previously (Heyndrickx et al, 1996b). The restriction patterns were analysed as described by Heyndrickx et al. (1998).

Percentage DNA-DNA binding. DNA-DNA binding reactions of representative strains of each species were determined spectrophotometrically by using the initial renaturation method of De Ley et al. (1970) and expressed as percentages, as described previously (Willems et al., 1989).

DNA base composition. Mean $\mathrm{G}+\mathrm{C}$ contents were determined using the thermal denaturation method (De Ley \& Van Muylem, 1963) and the equation of Marmur \& Doty (1962) as modified by De Ley (1970). The G $+C$ content of Virgibacillus sp. LMG 17368 was measured using the method of Tamaoka \& Komagata (1984).

Gas chromatographic analysis of fatty acid methyl esters (FAMEs). Cells were grown and analysed as described by Heyndrickx et al. (1998), using the methods of Vauterin et al. (1991).

SDSPAGE of whole-cell proteins. Cells were obtained as described by Heyndrickx et al. (1998), the SDS protein extracts prepared and electrophoresed according to Pot et al. (1994), and the data collected and interpreted as described by Vauterin \& Vauterin (1992).
Phenotypic characterization and numerical analysis. Strains were grown and maintained on TSA plus $\mathrm{MnSO}_{4}$, and characterization and numerical analysis followed the methods of Logan \& Berkeley (1984), as described by Heyndrickx et al. (1998).

165 rDNA sequencing. A fragment of the 16S rRNA gene (corresponding to positions 8-541 in the Escherichia coli numbering system) of $V$. proomii LMG $12370^{\mathrm{T}}$ was amplified by PCR using conserved primers (5'-AGAGTTTGATCCTGGCTGAG-3' and 5'-AAGGAGGTGATCCAGCCGCA-3'). The PCR products were purified using a QIAquick PCR Purification kit (Qiagen) according to the manufacturer's instructions. Sequencing was performed using an Applied Biosystems 377 DNA sequencer and the protocols of the manufacturer (Perkin-Elmer) using the ABI Prism Dye Terminator Cycle Sequencing Ready Reaction kit. The sequencing primers used were as described by Coenye et al. (1999). A dissimilarity matrix was constructed. The sequences of strains belonging to the same phylogenetic group were retrieved from the EMBL database and aligned with the consensus sequence via the TREECON software (Van de Peer \& De Wachter, 1997). A FASTA search (Pearson \& Lipman, 1988) was also completed via the EMBL sequence database.

\section{RESULTS AND DISCUSSION}

The 14 Virgibacillus strains were separated from all the other organisms studied in the numerical analysis of their combined ARDRA patterns, and were subdivided into two groups (Fig. 1). The largest group, formed at a similarity level of $92 \%$, comprised 10 strains and included the type strain of $V$. pantothenticus, LMG $71.29^{\mathrm{T}}$. Nearest neighbours of this group, joined at a similarity level of $80 \%$, were the 


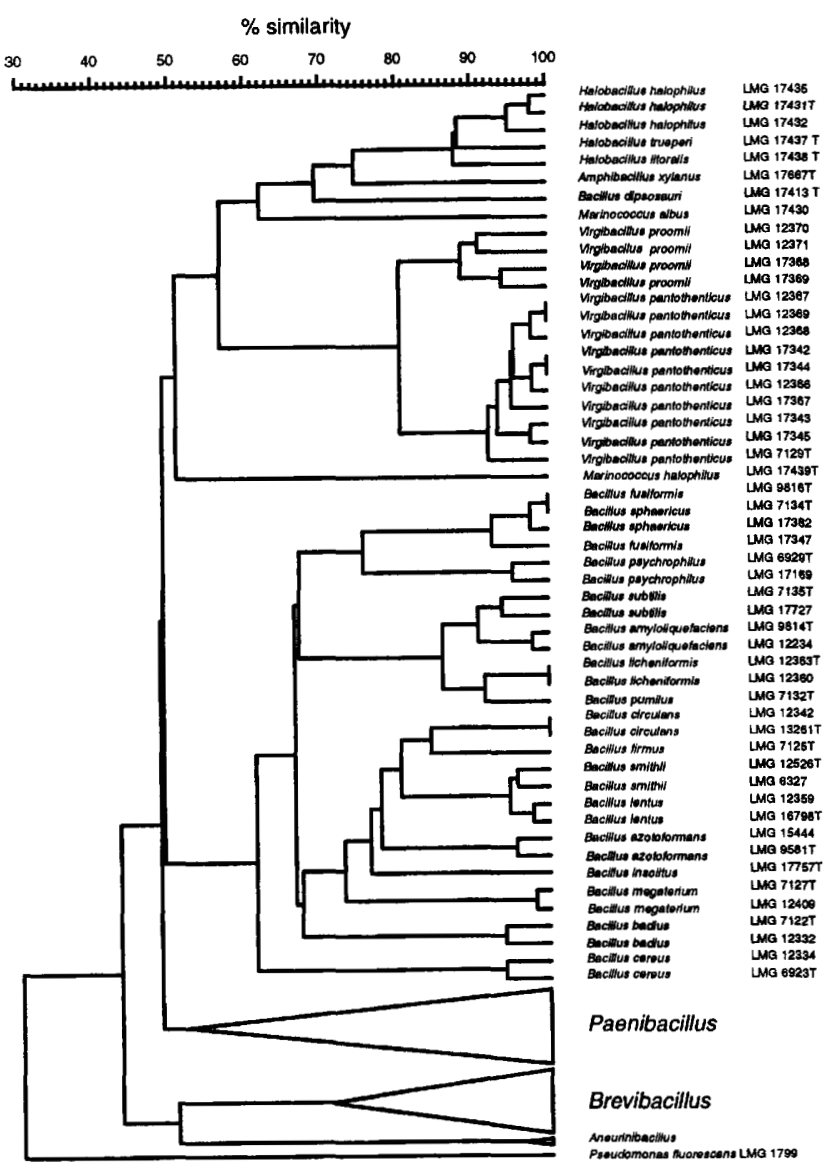

Fig. 1. Dendrogram based on UPGMA (unweighted pair group method with arithmetic averages) clustering of correlation coefficients of normalized 16S rDNA restriction profiles (ARDRA) of $V$. pantothenticus, $V$. proomii and a selection of Bacillus (sensu lato) strains belonging to different rRNA groups. four strains LMG 12370, 12371, 17368 and 17369 ; these showed $89 \%$ similarity to each other and form the group being proposed as the new species V. proomii.

From Table 2 it can be seen that the lowest dissimilarity in rDNA sequence was found between $V$. pantothenticus and $V$. proomii. The FASTA searches (not shown) did not reveal sequence similarities with other taxa of higher than $97 \%$, supporting the separate species status of Virgibacillus proomii.

Numerical analysis of SDS-PAGE patterns of wholecell proteins (Fig. 2) showed a similar arrangement of the Virgibacillus strains (except for strain LMG 12366) to that seen with ARDRA (Fig. 1): a large group (nine strains), including $V$. pantothenticus LMG $7129^{\mathrm{T}}$, showed identical protein patterns (similarity level of at least $89 \%$ ), and the four strains LMG 12370, 12371, 17368 and 17369 showed $88 \%$ similarity and linked with the larger Virgibacillus group at $76 \%$ similarity. The one exception was $V$. pantothenticus LMG 12366 , which was the nearest neighbour of the larger group of nine strains at $78 \%$ similarity. The aberrant clustering of this strain with respect to the ARDRA picture was merely caused by a dense protein band with a molecular mass of $5.6 \times 10^{4} \mathrm{Da}$. Indeed, by exclusion of this band from numerical analysis (Costas, 1992), this strain clustered within the group of nine strains containing the $V$. pantothenticus type strain (not shown).

Fatty acid profiles of the Virgibacillus strains are shown in Table 3. Although the profiles of both groups of strains show the major fatty acids to be iso- $\mathrm{C}_{15: 0}$ and anteiso- $\mathrm{C}_{15: 0}$, the ratios of these major components are quite different in each group; in $V$. pantothenticus the ratio is about $1: 3$, and in $V$.proomii it is $1: 1$. Furthermore, iso- $\mathrm{C}_{13: 0}$ is always lower than $0.5 \%$ of total fatty acids in $V$. pantothenticus, whilst it is at least $1 \%$ in $V$. proomii.

Table 2. 16S rDNA sequence dissimilarities (fraction of the observed difference per total number of compared nucleotides) for the type strains of $V$. pantothenticus and $V$. proomii, and representative strains of seven other related taxa

Key: 1, Amphibacillus xylanus JCM 7361;2, Virgibacillus pantothenticus NCDO $1765^{\mathbf{T}} ; 3$, Virgibacillus proomii LMG $12370^{\mathrm{T}} ; 4$, Bacillus salexigens $\mathrm{C} 20-\mathrm{Mo} ; 5$, Bacillus subtilis NCDO 1769; 6, Brevibacillus brevis NCIMB 9372; 7, Halobacillus litoralis SL-4; 8, Paenibacillus polymyxa NCDO 1774; 9, Halobacillus halophilus NCIMB 9251.

\begin{tabular}{|lccccccccc|}
\hline & 1 & $\mathbf{2}$ & $\mathbf{3}$ & $\mathbf{4}$ & $\mathbf{5}$ & $\mathbf{6}$ & $\mathbf{7}$ & $\mathbf{8}$ & $\mathbf{9}$ \\
\hline 2 & 0.07164 & 0.000 & & & & & & & \\
3 & 0.07163 & 0.02861 & 0.000 & & & & & & \\
4 & 0.09314 & 0.05015 & 0.04545 & 0.000 & & & & & \\
5 & 0.09765 & 0.07554 & 0.07631 & 0.08267 & 0.000 & & & & \\
6 & 0.09663 & 0.11180 & 0.11037 & 0.12221 & 0.10036 & 0.000 & & & \\
7 & 0.07838 & 0.05391 & 0.05871 & 0.06759 & 0.07616 & 0.09928 & 0.000 & & \\
8 & $0 \cdot 11176$ & 0.11706 & 0.11533 & 0.13014 & 0.12472 & 0.11386 & 0.12227 & 0.000 & \\
9 & 0.07433 & 0.05621 & 0.06211 & 0.07847 & 0.08834 & 0.10813 & 0.02019 & 0.12473 & 0.000 \\
\hline
\end{tabular}


Table 3. Comparison of the mean fatty acid profiles of $4 \mathrm{~V}$. proomii and $10 \mathrm{~V}$. pantothenticus strains as measured by GC analysis of FAMEs

The data given are mean values with the minimal and maximal values within the particular species given below. Only the fatty acids accounting for at least $0 \cdot 5 \%$ of the total fatty acid content are listed.

\begin{tabular}{|c|c|c|c|c|c|c|c|c|c|c|}
\hline Fatty acid & $\begin{array}{c}13: 0 \\
\text { iso }\end{array}$ & $\begin{array}{c}13: 0 \\
\text { anteiso }\end{array}$ & $\begin{array}{c}14: 0 \\
\text { iso }\end{array}$ & $14: 0$ & $\begin{array}{c}15: 0 \\
\text { iso }\end{array}$ & $\begin{array}{c}15: 0 \\
\text { anteiso }\end{array}$ & $\begin{array}{c}16: 0 \\
\text { iso }\end{array}$ & $16: 0$ & $\begin{array}{c}17: 0 \\
\text { iso }\end{array}$ & $\begin{array}{c}17: 0 \\
\text { anteiso }\end{array}$ \\
\hline \multirow[t]{2}{*}{$V$. proomii } & 1.9 & 0.64 & 6.0 & $2 \cdot 3$ & $33 \cdot 5$ & $33 \cdot 0$ & 4.9 & 7.6 & $4 \cdot 3$ & 5.8 \\
\hline & $0.96-3.9$ & $0 \cdot 00-1 \cdot 1$ & $2 \cdot 9-11 \cdot 4$ & $1.4-3.8$ & $23 \cdot 8-39 \cdot 9$ & $24 \cdot 0-40 \cdot 0$ & $3 \cdot 9-7.8$ & $5 \cdot 9-11 \cdot 0$ & $2 \cdot 5-6 \cdot 2$ & $1 \cdot 6-10 \cdot 6$ \\
\hline \multirow[t]{2}{*}{ V. pantothenticus* } & - & 0.5 & $4 \cdot 3$ & $1 \cdot 2$ & 15.8 & $47 \cdot 4$ & 8.3 & $5 \cdot 2$ & $2 \cdot 8$ & 13.5 \\
\hline & - & $0.0-0.87$ & $2 \cdot 7-6 \cdot 4$ & $0.7-1.6$ & $11 \cdot 9-19 \cdot 2$ & $37 \cdot 8-52 \cdot 0$ & $6 \cdot 4-11 \cdot 2$ & $3 \cdot 2-8 \cdot 1$ & $2 \cdot 1-3 \cdot 3$ & $10 \cdot 3-18 \cdot 9$ \\
\hline
\end{tabular}

* Data from Heyndrickx et al. (1998).

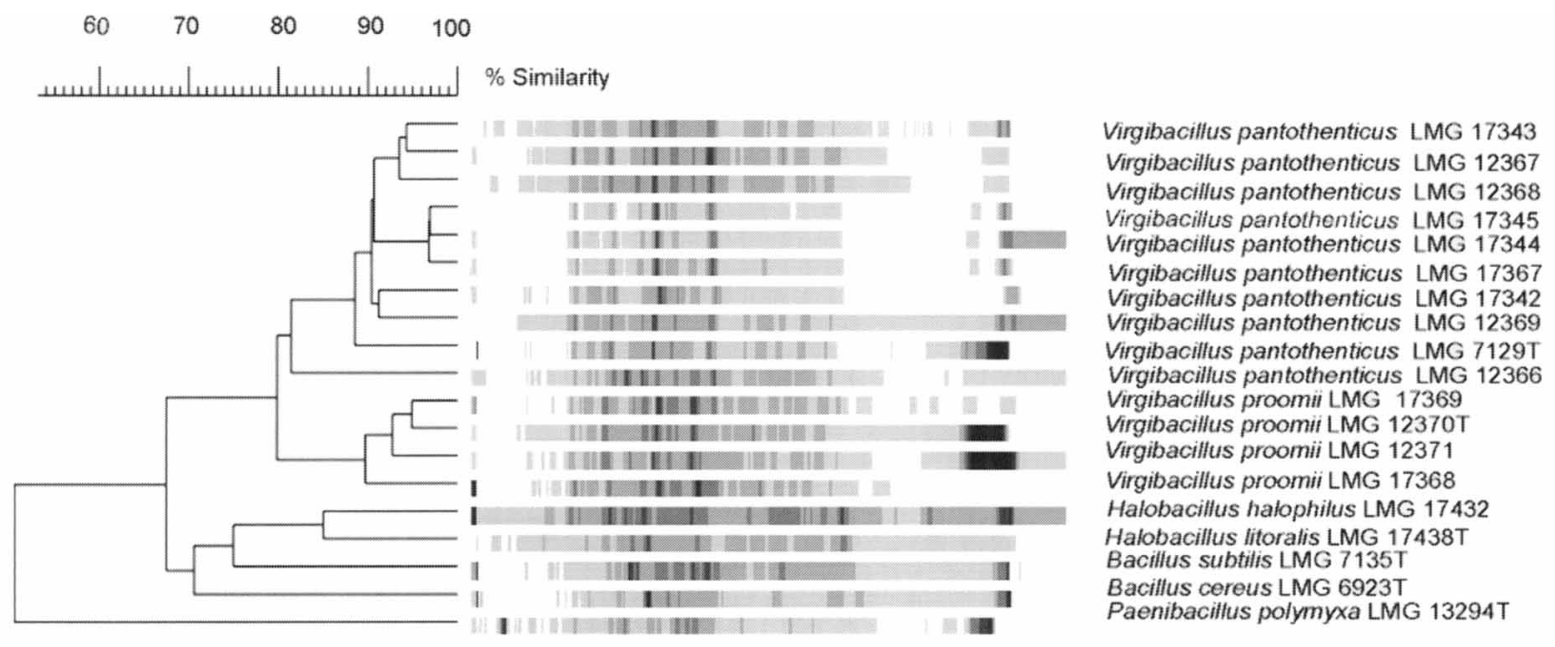

Fig. 2. Normalized computer profiles of protein patterns (PAGE) of $V$. pantothenticus and $V$. proomii strains, as well as representatives of Halobacillus, Bacillus and Paenibacillus as outgroups.

In the numerical analysis of API tests and other phenotypic characters (Fig. 3), the Virgibacillus strains were divided into two distinct clusters which merged at $77.5 \% S_{\mathrm{G}}$. The larger of the two Virgibacillus clusters formed at $85 \% S_{\mathrm{G}}$, and contained the same 10 strains that clustered together in the ARDRA (Fig. 1) and the revised PAGE dendrograms. The four remaining strains of Virgibacillus (LMG 12370, 12371, 17368 and 17369 ) clustered loosely at $82.5 \% S_{\mathrm{G}}$, a result also consistent with the findings of the other analyses. This separation reflects distinct biochemical and morphological profiles for the two sub-groups of Virgibacillus which allow their ready separation using routine tests (Table 4).

The DNA-DNA relatedness of the type strain of $V$. pantothenticus with $V$. proomii strain LMG 12370 was $23 \%$, whereas $V$. proomii strains LMG 12370 and 17368 showed $93 \%$ relatedness. These data confirm the distinction of the two Virgibacillus groups at the species level and support the recognition of the LMG $12370,12371,17368$ and 17369 group as a new species of Virgibacillus.
In conclusion, our polyphasic data show that the $V$. pantothenticus cluster contains two distinct taxa. The larger group of 10 strains contains the type strain of $V$. pantothenticus, whilst the smaller cluster, comprising four strains from different environments, is proposed as the new species Virgibacillus proomii, with LMG 12370 as the type strain. The description of the new species and an emended description of $V$. pantothenticus follow, and Table 4 shows characteristics for separating the two species and for their distinction from some other aerobic endospore-forming bacteria.

\section{Description of Virgibacillus proomii}

Virgibacillus proomii (proom.i.i. M.L. adj. proomii of Proom, referring to Harold Proom, the person who, with B. C. J. G. Knight, first isolated a member of this species and who described Bacillus pantothenticus).

Cells are motile, Gram-positive, usually long, rods $(0.5-0.7$ by $2-8 \mathrm{~mm})$ which sometimes, especially in older cultures, form chains and/or filaments. They bear spherical to ellipsoidal endospores which lie in 
Table 4. Characteristics for distinguishing between Virgibacillus species and some species of Bacillus, Halobacillus and Paenibacillus

,$+>85 \%$ positive; $(+), 75-84 \%$ positive; $v$, variable ( $26-74 \%$ positive) $(-), 16-25 \%$ positive;,$- 0-15 \%$ positive; w, weak positive reaction.

\begin{tabular}{|c|c|c|c|c|c|c|c|c|c|}
\hline Characteristic* & $V \cdot$ pantothenticus & $V \cdot$ proomii & B. circulans & B. subtilis & B. licheniformis & B. dipsosauri & P. polymyxa & P. validus & H. litoralis \\
\hline $\begin{array}{l}\text { Chains of cells and/or } \\
\text { filaments }\end{array}$ & + & + & $(-)$ & $(-)$ & $(+)$ & + & - & - & + \\
\hline \multicolumn{10}{|l|}{ Sporangia $\dagger$} \\
\hline Spore shape & ES & ES & $\mathrm{E}$ & $E$ & $\mathrm{E}$ & $\mathbf{s}$ & $\mathrm{E}$ & $\mathrm{E}$ & $\mathrm{E}(\mathbf{S})$ \\
\hline Spore position & $\mathrm{T}(\mathbf{S})$ & $\mathrm{T}(\mathrm{S})$ & ST & PS & PS & $\mathbf{T}$ & PS & ST & PS \\
\hline Sporangia swollen & + & + & + & - & - & + & + & + & + \\
\hline Anaerobic growth & + & + & + & - & + & - & + & - & - \\
\hline Gelatin hydrolysis & + & $\mathrm{v}$ & - & + & + & - & $\mathrm{v}$ & - & + \\
\hline Casein hydrolysis & + & + & - & + & + & - & + & - & - \\
\hline Gas from carbohydrates & - & - & - & - & - & - & + & - & - \\
\hline \multicolumn{10}{|l|}{ Acid from: } \\
\hline Amygdalin & + & - & + & + & + & + & + & - & - \\
\hline D-Arabinose & + & - & + & - & - & + & - & - & - \\
\hline L-Fucose & + & - & - & - & - & + & - & - & - \\
\hline Glycerol & + & - & $\mathrm{v}$ & + & + & + & + & + & w \\
\hline Glycogen & - & $\mathrm{v}$ & + & + & + & + & + & $\mathrm{v}$ & - \\
\hline meso-Inositol & - & + & + & + & $(+)$ & - & - & + & - \\
\hline Methylxyloside & - & - & + & - & - & + & + & - & - \\
\hline L-Rhamnose & + & $(-)$ & $(-)$ & - & + & + & $\mathrm{v}$ & - & - \\
\hline D-Turanose & + & - & + & + & + & - & + & + & w \\
\hline
\end{tabular}

* With the exception of microscopic observations, anaerobic growth and casein hydrolysis, all characteristics were determined using tests in API 20E and $50 \mathrm{CHB}$ systems.

† Spore shape: E, ellipsoidal; S, spherical. Spore position: P, central/paracentral; S, subterminal; T, terminal. Shapes or positions infrequently observed are shown in parentheses.

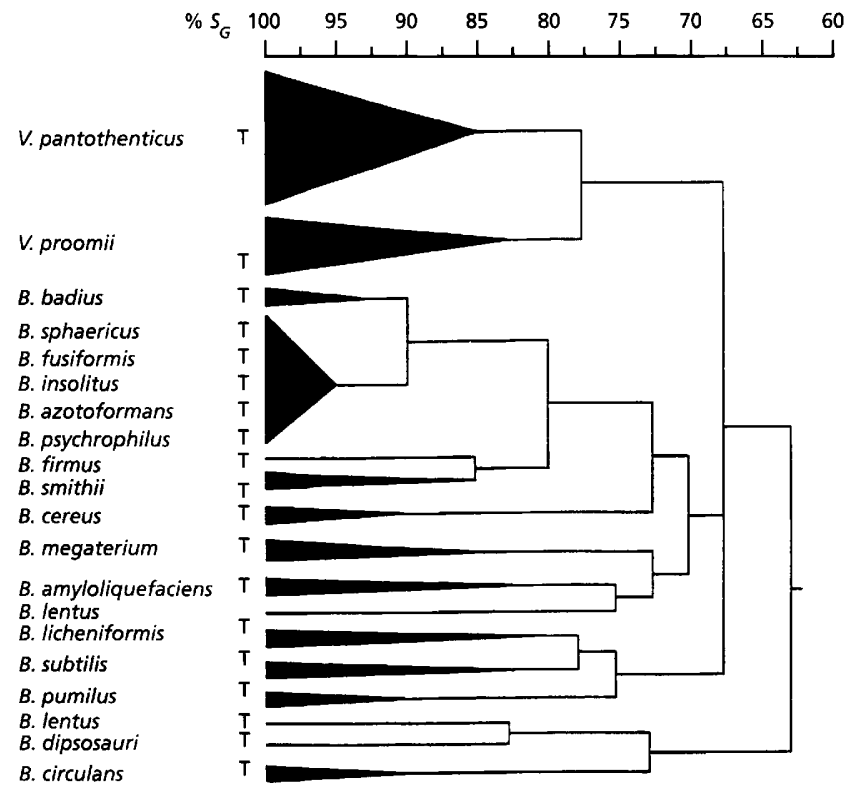

Fig. 3. Simplified phenogram based on the UPGMA clustering of similarity coefficients $\left(S_{G}\right)$ of 76 phenotypic characters of representatives of 14 Virgibacillus strains and of 32 representatives of 18 Bacillus species. T indicates position of type strain.

terminal, sometimes subterminal, positions in swollen sporangia (Fig. 4). After $2 \mathrm{~d}$ on TSA colonies are 1-4 $\mathrm{mm}$ in diameter, low convex, circular and slightly irregular, butyrous (sometimes slightly tenacious when

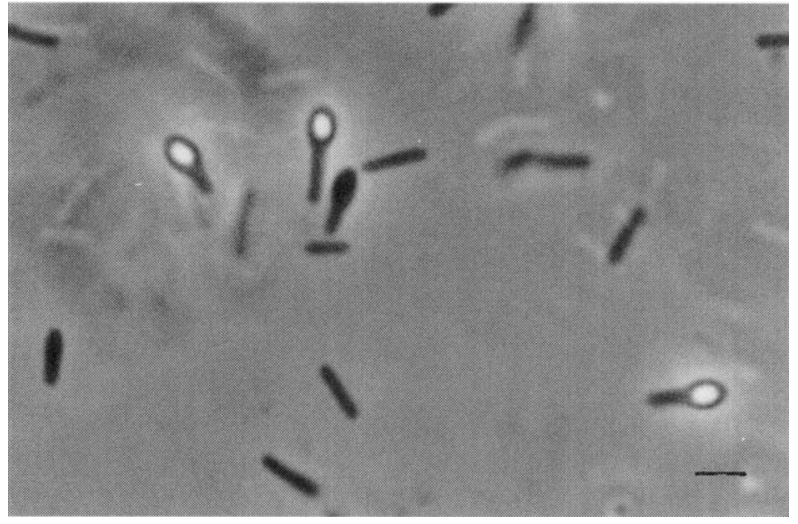

Fig. 4. Photomicrograph of sporangia and vegetative cells of the type strain of $V$. proomii viewed by phase-contrast microscopy; sporangia are swollen with subterminal to terminal ellipsoidal spores. Bar, $2 \mu \mathrm{m}$.

cells form filaments), creamy-grey and almost opaque with an eggshell or matt appearance; the appearance under $\times 10$ magnification is reminiscent of white soapflakes in a greyish matrix. After $4 \mathrm{~d}$ colonies smell of ammonia and are 5-10 $\mathrm{mm}$ in diameter with lobed and/or fimbriate margins. Organisms are facultatively anaerobic and catalase-positive, and they may have a nutritional requirement for pantothenic acid, thiamin, biotin and amino acids. The Voges-Proskauer reaction is negative. Hydrogen sulphide is not produced, but a few strains may give positive reactions for arginine 
dihydrolase and citrate utilization in the API 20E strip. Indole is not produced. Nitrate is not reduced to nitrite. Hydrolysis of aesculin and of casein positive; hydrolysis of gelatin usually positive. Growth may occur between 15 and $50^{\circ} \mathrm{C}$, with an optimum of about $37^{\circ} \mathrm{C}$. Acid without gas is produced from the following carbohydrates: $\mathrm{N}$-acetylglucosamine, arbutin, D-fructose, galactose, D-glucose, inositol, maltose, D-mannose, ribose, salicin, D-tagatose and trehalose. Acid production from the following carbohydrates is variable: amygdalin, cellobiose and gluconate (these three usually negative), glycogen, methyl $\alpha$-D-glucoside, rhamnose, starch and sucrose. Acid is not produced from the following carbohydrates: adonitol, D- or L-arabinose, D- or L-arabitol, dulcitol, erythritol, $\mathrm{D}$ - or L-fucose, $\beta$-gentiobiose, glycerol, inulin, 2-ketoD-gluconate, 5-keto-D-gluconate, lactose, D-lyxose, mannitol, D-melibiose, D-melezitose, methyl $\alpha$-D-mannoside, methylxyloside, D-raffinose, sorbitol, L-sorbose, D-turanose, xylitol or D- or L-xylose. The major cellular fatty acids are iso- $\mathrm{C}_{15: 0}$ and anteiso- $\mathrm{C}_{15: 0}$, present in about equal amounts. iso- $\mathrm{C}_{13: 0}$ is always present at a level of more than $0.5 \%$ of the total fatty acids. The $\mathrm{G}+\mathrm{C}$ content is $37 \mathrm{~mol} \%$ for the type strain, LMG $12370^{\mathrm{T}}$, and $36.8 \mathrm{~mol} \%$ for strain LMG 17368 ; the 16S rRNA sequence of the type strain is deposited at EMBL under accession number AJ012667. In the variable characters listed above, the type strain is weak for hydrolysis of gelatin; and acid without gas is produced from methyl $\alpha$-D-glucoside, starch and sucrose, but not from amygdalin, cellobiose, gluconate, glycogen and rhamnose.

\section{Emended description of Virgibacillus pantothenticus (Proom and Knight 1950, 539 ${ }^{\text {AL }}$ ) Heyndrickx et al. 1998}

Virgibacillus pantothenticus (pan.to.then'tic.us. M.L. acidum pantothenticum pantothenic acid; M.L. adj. pantothenticus relating to pantothenic acid).

Cells are motile, Gram-positive, usually long, rods $(0.5-0.7$ by $2-8 \mathrm{~mm})$ which sometimes, especially in older cultures, form chains and/or filaments. They bear spherical to ellipsoidal endospores which lie in terminal, sometimes subterminal, positions in swollen sporangia. After $2 \mathrm{~d}$ on TSA colonies are $1-4 \mathrm{~mm}$ in diameter, low convex, circular and slightly irregular, butyrous (sometimes slightly tenacious when cells form filaments), creamy-grey and almost opaque with an eggshell or glossy appearance; the appearance under $\times 10$ magnification is reminiscent of white soapflakes in a greyish matrix. After $4 \mathrm{~d}$ colonies smell of ammonia and are $5-10 \mathrm{~mm}$ in diameter with lobed and/or fimbriate margins. Organisms are facultatively anaerobic and catalase-positive. They have a nutritional requirement for pantothenic acid, thiamin, biotin and amino acids. The Voges-Proskauer reaction is negative. Hydrogen sulphide is usually not produced, but a few strains give weak positive reactions in the API 20E strip; a few strains also give positive reactions for arginine dihydrolase, citrate utilization, and $o$-nitrophenyl $\beta$-D-galactoside in the API $20 \mathrm{E}$ strip. Indole is not produced. Nitrate reduction to nitrite is variable. Hydrolysis of aesculin and of casein positive; hydrolysis of gelatin usually positive. Growth is stimulated by $4 \% \mathrm{NaCl}$ and not inhibited by $10 \%$ $\mathrm{NaCl}$. Growth may occur between 15 and $50^{\circ} \mathrm{C}$, with an optimum of about $37^{\circ} \mathrm{C}$. Acid without gas is produced from the following carbohydrates: $N$-acetylglucosamine, D-arabinose, arbutin, D-fructose, galactose, D-glucose, glycerol, maltose, D-mannose, methyl $\alpha$-D-glucoside, rhamnose, ribose, salicin, starch, sucrose, D-tagatose, trehalose and D-turanose. Acid production from the following carbohydrates is variable: amygdalin, cellobiose, L-fucose, $\beta$-gentiobiose, gluconate, lactose, methyl $\alpha$-D-mannoside and sorbitol. Acid is not produced from the following carbohydrates: adonitol, L-arabinose, D- or L-arabitol, dulcitol, erythritol, D-fucose, glycogen, inositol, inulin, 2-keto-D-gluconate, 5-keto-D-gluconate, D-lyxose, mannitol, D-melibiose, D-melezitose, methylxyloside, D-raffinose, L-sorbose, xylitol or D- or L-xylose. The major cellular fatty acids are iso- $\mathrm{C}_{15: 0}$ and anteiso$\mathrm{C}_{15: 0}$ in a ratio of $1: 3$; iso- $\mathrm{C}_{13: 0}$ is present at a level of less than $0.5 \%$ of the total fatty acid content. The major quinone is menaquinone 7 (Watanuki \& Aida, 1972). Murein of the type strain has been reported as meso-DAP direct type (Claus \& Berkeley, 1986). The $\mathrm{G}+\mathrm{C}$ content is $36.9 \mathrm{~mol} \%$ for the type strain, $\mathrm{LMG}$ $7129^{\mathrm{T}}$. In the variable characters listed above, its reactions are positive for $\mathrm{H}_{2} \mathrm{~S}$ production (weak), citrate utilization, gelatin hydrolysis, and production of acid without gas from amygdalin, cellobiose and methyl $\alpha$-D-mannoside; its reactions are negative for arginine dihydrolase, nitrate reduction, ONPG, and production of acid without gas from L-fucose, $\beta$-gentiobiose, gluconate, lactose and sorbitol.

\section{ACKNOWLEDGEMENTS}

We are most grateful to bioMérieux for providing API materials and for supporting G.F; P.D.V. and M.H. are indebted to the National Fund for Scientific Research (Belgium) for a position as Senior Research Associate and Postdoctoral Research Fellow, respectively. M.H., N.A.L. and P.D.V. are most grateful to the British Council and the Fund for Scientific Research (Belgium) for the award of an Academic Research Collaboration Programme travel grant. P.D.V. thanks the 'Onderzoeksfonds RUG' for personnel and research grants nos 01105893 and 011A1096. K.K. acknowledges the Fund for Medical Scientific Research (Belgium) for personnel and research grants.

\section{REFERENCES}

Ash, C., Farrow, J. A. E., Wallbanks, S. \& Collins, M. D. (1991). Phylogenetic heterogeneity of the genus Bacillus revealed by comparative analysis of small-subunit-ribosomal RNA sequences. Lett Appl Microbiol 13, 202-206.

Claus, D. \& Berkeley, R. C. W. (1986). Genus Bacillus Cohn 1872. In Bergey's Manual of Systematic Bacteriology, vol. 2, pp. 1105-1139. Edited by P. H. A. Sneath, N. S. Mair, M. E. Sharpe \& J. G. Holt. Baltimore: Williams \& Wilkins. 
Coenye, T., Falsen, E., Vancanneyt, M., Hoste, B., Govan, J. R. W., Kersters, K. \& Vandamme, P. (1999). Classification of Alcaligenes faecalis-like isolates from the environment and human clinical samples as Ralstonia gilardii sp. nov. Int J Syst Bacteriol 49, 405-413.

Costas, M. (1992). Classification, identification, and typing of bacteria by the analysis of their one-dimensional polyacrylamide gel electrophoretic protein patterns. In Advances in Electrophoresis, vol. 5, pp. 351-408. Edited by A. Chambrach, M. J. Dunn \& B. J. Radola. Weinheim: VCH.

De Ley, J. (1970). Re-examination of the association between melting point, buoyant density and chemical base composition of deoxyribonucleic acid. $J$ Bacteriol 101, 738-754.

De Ley, J. \& Van Muylem, J. (1963). Some applications of deoxyribonucleic acid base composition in bacterial taxonomy. Antonie Leeuwenhoek 29, 344-358.

De Ley, J., Cattoir, H. \& Reynaerts, A. (1970). The quantitative measurement of DNA hybridization from renaturation rates. Eur J Biochem 12, 133-142.

Gordon, R. E., Haynes, W. C. \& Pang, C. H.-N. (1973). The genus Bacillus. Agriculture Handbook no. 427, p. 283. Washington, DC: US Department of Agriculture.

Heyndrickx, M., Vandemeulebroecke, K., Hoste, B., Janssen, P., Kersters, K., De Vos, P., Logan, N. A., Ali, N. \& Berkeley, R. C. W. (1996a). Reclassification of Paenibacillus (formerly Bacillus) pulvifaciens (Nakamura 1984) Ash et al., 1994, a later subjective synonym of Paenibacillus (formerly Bacillus) larvae (White 1906) Ash et al., 1994, as a subspecies of $P$. larvae, emended descriptions of $P$. larvae as $P$. larvae subsp. larvae and $P$. larvae subsp. pulvifaciens. Int $J$ Syst Bacteriol 46, 270-279.

Heyndrickx, M., Vauterin, L., Vandamme, P., Kersters, K. \& De Vos, P. (1996b). Applicability of combined amplified 16S rDNA restriction analysis (ARDRA) patterns in bacterial phylogeny and taxonomy. $J$ Microbiol Methods 26, 247-259.

Heyndrickx, M., Lebbe, L., Kersters, K., De Vos, P., Forsyth, G. \& Logan, N. A. (1998). Virgibacillus: a new genus to accommodate Bacillus pantothenticus (Proom and Knight 1950). Emended description of Virgibacillus pantothenticus. Int J Syst Bacteriol 48, 99-106.

Logan, N. A. \& Berkeley, R. C. W. (1984). Identification of Bacillus strains using the API system. J Gen Microbiol 130, 1871-1882.
Marmur, J. \& Doty, P. (1962). Determination of the base composition of deoxyribonucleic acid from its thermal denaturation temperature. $J \mathrm{Mol}$ Biol 5, 109-118.

Pearson, W. R. \& Lipman, D. J. (1988). Improved tools for biological sequence comparison. Proc Natl Acad Sci 85, 2444-2448.

Pitcher, D. G., Saunders, N. A. \& Owen, R. J. (1989). Rapid extraction of bacterial genomic DNA with guanidium thiocyanate. Lett Appl Microbiol 8, 151-156.

Pot, B., Vandamme, P. \& Kersters, K. (1994). Analysis of electrophoretic whole organism protein fingerprints. In Chemical Methods in Prokaryotic Systematics, pp. 493-521. Edited by M. Goodfellow \& A. G. O’Donnell. Chichester: Wiley.

Proom, H. \& Knight, B. C. J. G. (1950). Bacillus pantothenticus (n.sp.). J Gen Microbiol 4, 539-541.

Tamaoka, J. \& Komagata, K. (1984). Determination of DNA base composition by reversed-phase high-performance liquid chromatography. FEMS Microbiol Lett 25, 125-128.

Van de Peer, Y. \& De Wachter, R. (1997). Construction of evolutionary distance trees with TREECON for Windows: accounting for variation in nucleotide substitution rate among sites. Comput Appl Biosci 13, 227-230.

Vauterin, L. \& Vauterin, P. (1992). Computer aided objective comparison of electrophoretic patterns for grouping and identification of microoganisms. Eur Microbiol 1, 37-41.

Vauterin, L., Yang, P., Hoste, B., Vancanneyt, M., Civerolo, E. L., Swings, J. \& Kersters, K. (1991). Differentiation of Xanthomonas campestris pv. citri strains by sodium dodecyl sulfate-polyacrylamide gel electrophoresis of proteins, fatty acid analysis, and DNA-DNA hybridization. Int $J$ Syst Bacteriol 41, 535-542.

Watanuki, M. \& Aida, K. (1972). Significance of quinones in the classification of bacteria. J Gen Appl Microbiol 18, 469-472.

Willems, A., Busse, J., Goor, M. \& 8 other authors (1989). Hydrogenophaga, a new genus of hydrogen-oxidizing bacteria that includes Hydrogenophaga flava comb. nov. (formerly Pseudomonas flava), Hydrogenophaga palleronii (formerly Pseudomonas palleronii), Hydrogenophaga pseudoflava (formerly Pseudomonas pseudoflava and 'Pseudomonas carboxydoflava'), and Hydrogenophaga taeniospiralis (formerly Pseudomonas taeniospiralis). Int J Syst Bacteriol 39, 319-333. 